Jakub JAKUBOWSKI

Uniwersytet im. Adama Mickiewicza w Poznaniu

\title{
Rekwizyt jako narzędzie komunikowania politycznego
}

„Pieczołowicie wypracowany wizerunek sceniczny powinien on uznać za swą naturę. [...] Grać znaczy tyle, co stać się nim. Granica pomiędzy być i grać jest granicą pozorną".

Niccolò Machiavelli, Ksiaże

\section{Wstęp}

7 miana ustroju politycznego, powstanie niezależnych mediów, ewolu-

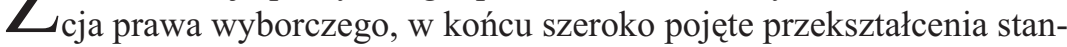
dardów życia społecznego stanowią główne przyczyny głębokich przemian w procesie komunikowania politycznego w Polsce. Przez ponad dwadzieścia lat rozwoju instytucji demokratycznych, wzorując się na dojrzałości w tej dziedzinie państw zachodnich, umiejętność posługiwania się przez aktorów rodzimej sceny politycznej narzędziami marketingu politycznego ulegała systematycznej ewolucji. Doprowadziło to do znacznej profesjonalizacji w dziedzinie relacji na linii aktor-widownia. Jednym z licznych przejawów rozwoju w dziedzinie komunikacji politycznej jest pojawienie się rekwizytu jako wielofunkcyjnego narzędzia, wpisującego się w standardy życia politycznego ujmowanego w ramy analogii do gry scenicznej. Warto wobec tego zadać kilka pytań i podjąć rozważania, na temat roli oraz funkcji rekwizytu, w szczególności biorąc pod uwagę jego marketingowe zastosowanie.

Po pierwsze, istotna wydaje się kwestia na ile zabiegiem świadomym i zaplanowanym jest wykorzystanie rekwizytu w komunikacji na linii aktor-widownia. Wydaje się, biorąc pod uwagę wszechobecność kultury obrazu oraz media pełniące funkcję gate keepera, iż w coraz większym stopniu aktorzy są zmobilizowani do podejmowania rywalizacji o czas 
i zainteresowanie publiczności. Bez względu na motywację działania aktora, w jego interesie jest jak najdłuższe pozostanie na scenie oraz zachowanie wysokiego poziomu popularności. Ta z kolei jest najistotniejszym warunkiem podtrzymania społecznego mandatu. Wszystko to wydaje się mieć zasadniczy wpływ na wzrost samoświadomości aktora w zakresie budowania swojego wizerunku w mediach. Drugą istotną kwestią jest sprawa narzędzi wykorzystywanych w komunikowaniu politycznym, rozważana z perspektywy marketingowego zastosowania rekwizytu. Skuteczność komunikacji zależy bowiem od jakości nadanego komunikatu i technik użytych w celu wywołania pożądanej reakcji. Wobec tego aktorzy prowokują publiczność niekonwencjonalnymi występami, wykorzystują humor w celu uatrakcyjnienia przekazu, przyzwyczajają widownie do stałych elementów swojego wizerunku czy posługują się rekwizytem jako bronią lub dowodem winy przeciwko swoim oponentom. Zabiegi te, które z pewną subtelnością korzystają z technik wywierania wpływu, posiadają formę perswazyjnego komunikatu wizualnego, który ma wywołać oczekiwaną reakcję. Stąd istotna i warta analizy kwestia wykorzystywania konkretnych narzędzi i ich skuteczności. Kolejne nasuwające się pytanie brzmi: w jakim celu aktor podejmuje się tak - nierzadko - skomplikowanej czynności? Czy potrzeba wzbudzenia sympatii, zdobycia popularności, wyróżnienia się szczególną cechą na tle politycznych „szaraków” to jedyne i ostateczne cele zabiegów wizerunkowych z użyciem rekwizytu? Unaocznienie ostatecznych motywów każdej ze stron politycznej komunikacji nie jest wprawdzie łatwe, ale analizując bilans korzyści i strat w przypadku danego wydarzenia politycznego, można dojść do wniosku, iż pewne powtarzające się determinanty dają prawo do znajdywania $\mathrm{w}$ tej kwestii satysfakcjonujących uogólnień.

Uwzględniając specyfikę wykorzystywania rekwizytu jako narzędzia marketingu, zasadna jest analiza przedstawionego problemu z punktu widzenia komunikowania politycznego. Biorąc pod uwagę części składowe tego pojęcia, będzie to rozpowszechnianie informacji mającej wpływ na system władzy. Brian McNair znacznie głębiej zanurza się jednak w tą tematykę, biorąc pod uwagę takie jej elementy jak: mówioną i pisaną retorykę polityczną, akty komunikowania, znaki paralingwistyczne czy intencje nadawców co do wpływania na środowisko polityczne. Analizując owe składniki pojęcia, należy przyjąć iż, komunikowanie polityczne to wygłaszane lub pisemne oświadczenia oraz wizualne środki znaczeniowe (ubiór, makijaż, logo, fryzura, rekwizyt) - tzn. wszystkie te 
elementy komunikowania, o których można stwierdzić, iż tworzą polityczny wizerunek czy tożsamość ${ }^{1}$. Wymiana specyficznego typu informacji, będąca celem komunikowania politycznego, odbywa się pomiędzy trzema zasadniczymi podmiotami tego procesu: nadawcą (aktorem), pośrednikiem (mediami) i odbiorcą. Z punktu widzenia analizowanego problemu ten pierwszy element wydaje się być tu najbardziej istotny.

Aktorzy polityczni to partie polityczne, organizacje społeczne, grupy nacisku oraz organizacje terrorystyczne. Można w ten sposób określić jednostkę lub grupę jednostek, które zabiegają o wpływ na podejmowanie decyzji. Mogą to czynić za pomocą próby zdobycia realnej władzy, lub wywierania na nią nacisku ${ }^{2}$. Aktor posiada określoną scenariuszem rolę i dysponuje wskazówkami wyjaśniającymi tożsamość danego wydarzenia politycznego. Jego organizatorzy przejmują zaś rolę reżysera budując między innymi choreografię ceremonii ${ }^{3}$. Realia polityczne wymagają od aktorów ciagłych zabiegów promocyjnych, co skutkuje ,permanentną kampanią", w której to aktorzy działają w trybie ciąłego „stanu podwyższonej gotowości”. W takich realiach badania nad komunikowaniem politycznym mają praktycznie stały dopływ materiałów do naukowej analizy. Jest to sytuacja w której media stają w pozycji uprzywilejowanej, gdyż wzmożona potrzeba obecności aktorów w mediach, daje tym drugim możliwość dyktowania warunków ich pojawienia się na antenie czy na łamach prasy ${ }^{4}$. David Marshall uważa, iż pierwowzorem kampanii wyborczej staje się dziś kampania reklamowa, gdzie media tworzą z obywateli konsumentów, oddziałują na wielkie zbiorowości, odwołują się do sfery irracjonalnej ${ }^{5}$.

Spoglądając na problem z punktu widzenia samego aktora można stwierdzić za Fritzem Plassnerem, iż polityka uległa „medifikacji” - zaczęła kierować się w swoich działaniach logiką funkcjonowania mediów

1 B. McNair, Wprowadzenie do komunikowania politycznego, Poznań 1998, s. 26.

Ibidem, s. 26-31.

${ }^{3}$ D. Dayan, E. Katz, Wydarzenia medialne. Historia transmitowana na żywo, Warszawa 2008, s. 145-146.

${ }^{4}$ D. Piontek, Politycy i media. Sposoby wplywania przez polityków na zawartość mediów, w: Polska scena polityczna. Środowiska - komunikacja polityczna - strategie, red. K. Sobolewska-Myślik, A. Hess, K. Kowalczyk, Kraków 2010, s. 7.

5 D. Marshall, Celebrity and Power: Fame in Contemporary Culture, Minneapolis 1997, s. 205. 
masowych ${ }^{6}$. Z każdą kampanią wyborczą czy innym wydarzeniem wymagającym zaangażowania technik wywierania wpływu społecznego, coraz wyraźniej zaznacza się prawidłowość, iż istotnym dla interesu danego środowiska politycznego czy kandydata jest odpowiednie wykreowanie i poprowadzenie jego medialnego wizerunku, a nie przedstawienie polityka w świetle jego autentycznych zalet. Sprzyja temu zjawisko amerykanizacji kampanii, czyli przenoszenia standardów komunikacji politycznej ze Stanów Zjednoczonych w inne rejony świata. Joe McGinniss twierdzi, iż należy sprawę traktować szerzej - przemianie ulega cała sfera polityczna ${ }^{7}$. Amerykanizacja, modernizacja czy mediatyzacja zwiastują nadejście „polityki wizerunku”, gdzie „opakowanie i otoczka” wokół aktora mają większe znaczenie niż sama gra. Istotną kwestią staje się więc nie tylko wygląd czy ubiór, ale także sposób organizacji i przygotowania zjazdów partyjnych czy konferencji. Chodzi tu o obrazy łatwo rozpoznawalne i przyswajalne, które będą wywoływać odpowiednie skojarzenia i preferowane zachowania wyborców ${ }^{8}$. W takim świecie, jak twierdzi Danilo Zolo, „telegeniczność” staje się podstawowym kryterium politycznym ${ }^{9}$.

\section{Polityka jako gra sceniczna}

Analogia życia społecznego do teatru jest nie tylko jednym ze sposobów badania stosunków międzyludzkich, ale i formą przedstawiania wzajemnych relacji jednostek w społeczeństwie. Trudno odmówić w tym miejscu zasług Ervingowi Goffmanowi, który jako pierwszy dokonał pełnej i wnikliwej analizy stosunków społecznych, wpisując je w konwencję wydarzenia scenicznego. Słusznie zauważa w tej kwestii Robert E. Park, iż pierwszym znaczeniem słowa „osoba” (person) jest słowo „maska"10. Każde spotkanie człowieka z inną jednostką to ,spektakl” odgrywany na „scenie” przy użyciu odpowiedniej pozy. Warto pokusić

6 W. Schulz, Komunikacja polityczna. Koncepcje teoretyczne $i$ wyniki badań empirycznych na temat mediów masowych w polityce, Kraków 2006, s. 179.

J. McGinniss, The Selling of a President, New York 1969, s. 23.

8 J. Street, Mass media, polityka, demokracja, Kraków 2006, s. 163.

9 D. Zolo, Democracy and Complexity, Cambridge 1992, za: J. Street, op. cit., S. 161 .

10 R. E. Park, Race and Culture, Glencoe 1950, za: E. Goffman, Człowiek w teatrze życia codziennego, Warszawa 2000. 
się tu o przełożenie analogii polityki do gry scenicznej z gruntu socjologii na obszar badawczy politologii. Jak stwierdził Paweł Mościcki - „postać polityka jest dzisiaj nieuchronnie kojarzona $\mathrm{z}$ aktorstwem, gwiazdorstwem, ogólnie rzecz biorąc $-\mathrm{z}$ występowaniem" "11. Posługiwanie się pewnego rodzaju teatralnym żargonem oraz spłaszczanie rzeczywistości - scena stanowi wszakże przedstawienie realnego świata w sposób uproszczony - prowadzi do oddzielenia polityki od życia i uznania jej za umowną sferę ${ }^{12}$. Mimo iż nieco uproszczona, jest to jednak analogia trafna - dzięki niej możliwe jest zaobserwowanie wielu zależności między aktorami uczestniczącymi w spektaklu. Paralela ta zauważona została już w literaturze myślicieli starożytnych, choć jak zapewnia Stanisław Filipowicz, pierwszym imponującym przykładem przenikliwości odsłaniającej sekrety politycznego teatru zdarzeń jest Ksiaże Niccolò Machiavellego ${ }^{13}$. Istotnie, obraz manipulacji i kreowania wizerunku w tym klasycznym dziele, to bez watpienia pierwszy wykład z politycznego public relations stanowiący dobrą podstawę dla dzisiejszego PR.

Tak jak w naukach o komunikowaniu, tak i w socjologicznym ujęciu życia w konwencji teatru, na scenie występuje aktor, odgrywający swoją rolę ,polityka" "14. Jego maska musi być przede wszystkim przystosowana do obrazu, jaki chce dostrzec widownia oddająca głos w wyborczym castingu, który pozwala aktorowi wejść na scenę. W dobie ery komputera, w której osoby pełniące funkcje publiczne są pod niemal stałą obserwacją zarówno mediów tradycyjnych, jak i tych nowych, aktor zmuszony jest do odgrywania swojej roli polityka praktycznie wszędzie tam, gdzie może zostać dostrzeżony. Jego scena staje się przez to bardzo rozległym przestrzennie obszarem, pozostawiając niewiele miejsca na kulisty, gdzie maska może zostać zdjęta.

Wśród elementów teatru życia politycznego wymienić należy między innymi: scenę, aktorów, kulisy, scenografię, chór czy kostium. Częścią tego polityczno-teatralnego świata jest także rekwizyt, który w komunikowaniu między aktorem a widownią posiada szczególne znaczenie, będąc zarówno źródłem symboli, wzorców, jak i emocji. Efektem tego

11 P. Mościcki, Teatr angażujacy, „Gazeta Wyboracza” z dnia 15.04.2006 r., S. 12.

12 P. Pawełczyk, Socjotechniczne aspekty gry politycznej, Poznań 2000, s. 19.

13 S. Filipowicz, Mit i spektakl władzy, Warszawa 1988, s. 213.

14 P. Pawełczyk, op. cit., s. 23 i n. 
ma być wywieranie wpływu na ludzi i wywołanie określonych postaw. Jak twierdzi Andrzej Kijowski, rekwizyt to „element przedmiotowy, który niezależnie od związanej z właściwym mu systemem elementarnym funkcji ilustracyjnej, pełni jeszcze instrumentalną, swoistą dla niego rolę" ${ }^{, 15}$. Rekwizyty stanowią więc sprzęty niezbędne do wystawienia sztuki, także tej politycznej; są odpowiedzialne za kreowanie równoległej do świata realnego rzeczywistości, dookreślają właściwy odbiór sztuki i nadają jej klimat. Najistotniejsza z punktu widzenia podjętego tematu jest jednak pomoc rekwizytu w tworzeniu relacji aktor-widz. Każdy członek widowni jest wszakże obserwatorem, który tworzy w swoim umyśle wizerunek polityka znajdującego się na scenie. Można w tym sensie stwierdzić za Williamem Jamesem, iż aktor na politycznej scenie ma tyle społecznych ,ja”, ile jest grup ludzi, na których mu zale$\dot{z} y^{16}$. Już wspomniany N. Machiavelli postulował docenienie wizualnych elementów znajdujących się na politycznej scenie, aby zachować odpowiednią godność sprawowanego przez siebie urzędu - to jest - uwiarygodnienia swojej scenicznej maski. Stąd tak duże - według włoskiego pisarza - znaczenie majestatycznej dekoracji czy kostiumu.

Rekwizyt ma za zadanie udramatyzować akcję, nadać jej odpowiednią rangę. Poprzez wzbudzenie określonych skojarzeń i posługując się nierzadko symbolem, wywołuje on u publiczności określone reakcje i wprowadza pożądaną atmosferę na widowni. Dramatyczny kontekst działań związanych ze sferą polityczną zmusza coraz częściej aktora do docenienia roli scenariusza, inscenizacji kostiumów i rekwizytów ${ }^{17}$. „Każda sytuacja społeczna jest sytuacją o charakterze dramatycznym, a więc sytuacją, w której działanie ma symboliczny sens - coś przedstawia, wyraża, zostało zainscenizowane z myślą o przekazaniu pewnej wiadomości, o zademonstrowaniu określonej postawy, dzięki odpowiednio dobranym gestom, słowom, rekwizytom ${ }^{18}$. Warto dodać, iż wraz ze wzrastającym rozchwianiem społecznym, wzrasta także poziom udramatyzowania danego wydarzenia scenicznego. Wraz z pojawieniem się emocji i załamaniem pewnego ładu, zmianom ulegają także nastroje nie

\footnotetext{
5 A. T. Kijowski, Chwyt teatralny (zarys instrumentalnej teorii teatru), Kraków 1982, s. 34.

16 W. James, The Philosophy of William James, New York 1925, za: M. Carlson, Performans, Warszawa 2007, s. 75.

17 S. Filipowicz, op. cit., s. 218.

18 Ibidem, s. 219.
} 
tylko po stronie aktorów, ale także na widowni. Wzrasta zarówno poziom wyrazistości widowiska, jak i wzburzają się społeczne nastroje, co jednocześnie skutkuje zmianą scenicznego języka, tematyki, rekwizytów i wszelkich innych elementów, które stanowią osnowę społecznej dramaturgii ${ }^{19}$.

Rekwizyt jako element politycznej sceny ma być też wyrazem odpowiedniej estetyki, którą reżyser czy twórca danego politycznego spektaklu chce zachować na scenie. Rozpowszechnianie się pewnej wizji estetycznej wspomaga ekspansję polityczną. Do niej zaliczyć można takie elementy jak formy plastyczne czy muzyczne, specyficzną retorykę, kostiumy, gesty i dekoracje, które dla widza siedzącego na widowni wydają się wszechogarniające i reprezentują pewną całościową wizję czy nawet odzwierciedlają pewien styl życia ${ }^{20}$. Warto jednocześnie dodać, iż teatralizacja życia społecznego nie ma ram czasowych ani przestrzennych. Stanisław Powołocki twierdzi, iż ,instynkt teatralności” jest wrodzony człowiekowi i jest to nieodłączna cecha życia społecznego istot ludzkich. Instynkt ten modeluje życie państw, miast i narodów, narzucając politycznym sytuacjom dekoracje, kostiumy i postacie ${ }^{21}$. Marwin Carlson do uogólnienia przestrzennego dokłada jeszcze generalizację czasową stwierdzając, iż każda epoka historyczna ma własne kostiumy, dekorację i własną „maskę,"22.

\section{Funkcje rekwizytu w komunikowaniu politycznym}

Rekwizyt jako narzędzie komunikowania w sferze polityki może spełniać różne funkcje, w zależności od intencji jakimi kieruje się aktor. Pierwszą z nich jest deprecjacja politycznego przeciwnika, co bezpośrednio łączy tego typu zabiegi z pojęciem kampanii negatywnej. Definiować ją w tym kontekście należy jako listę zabiegów bądź działań manipulacyjnych, prowadzących do zdyskredytowania przeciwnika w oczach opinii publicznej, celem zmniejszenia jego popularności jako aktora grającego na politycznej scenie. Negatywizm w przekazywaniu informacji ma za zadanie unaocznienie publiczności faktów w taki

19 Ibidem, s. 220.

20 Ibidem, s. 225.

21 S. Powołocki, Mój romans z teatrem, Łódź 1997, s. 116.

22 M. Carlson, Performans, Warszawa 2007, s. 65. 
sposób, by za pomocą emocji wywołać silne wrażenie u odbiorców - prowokować i poruszać ${ }^{23}$. Lepsza „zapamiętywalność” tego typu przekazów sprawia, iż są one coraz powszechniejsze, a w niektórych kampaniach w zachodnich demokracjach już dawno zaczęły dominować. Stają się pewną formą manipulacji, będąc środkiem rujnowania zaufania, a nie jego budowania, co powinno stanowić nadrzędną wartość public relations ${ }^{24}$.

Efekt ten często uzyskiwany jest za pomocą rekwizytów związanych z osobą kontrkandydata, mających na celu zdyskredytowanie go w oczach publiczności obserwującej spektakl przez pryzmat mediów. Częstokroć negatywna kampania ma za zadanie oskarżenie oponenta o czyn dyskredytujący go w oczach wyborców. Ci natomiast, sprowokowani do wydania wyroku wymagają dowodu winy. Wydaje się, iż nie ma doskonalszego świadectwa niż zmaterializowany przedmiot, którego istnienia w sensie fizycznym nie sposób zanegować. Podczas gdy możliwe jest zaprzeczenie faktom, wyparcie się określonych przekonań i znajomości, zamarkowanie niektórych negatywnych cech charakteru, tak przedstawiony publicznie przedmiot ma charakter niepodważalny przez sam fakt swojego jestestwa. W tym miejscu przestrzeń dla swojej skuteczności znajdują rekwizyty, którymi posługiwanie się ma za zadanie zdyskredytować przeciwnika politycznego na polu rywalizacji.

Owa dyskredytacja to jednak nie tylko rozpowszechnianie o nim nieprawdziwych informacji, ale również inne zabiegi, które mają na celu przedstawienie za pomocą mediów masowych niekorzystnego obrazu konkurenta społeczeństwu. Tutaj również powszechnie wykorzystywany jest rekwizyt, jako element, który może w sposób pejoratywny wpłynąć na profil symboliczny kontrkandydata. Jednym z zabiegów jest ośmieszenie politycznego konkurenta. Wykorzystanie komizmu jest deprecjonującym działaniem, gdyż polityka jako scena, na której rozgrywa się spektakl władzy, nie powinna być widowiskiem komediowym. Istnieje co prawda w literaturze wizerunek „błazna” rozładowującego napięcie ironicznym stosunkiem do kwestii politycznych. Ten element klasyfikacji ról partyjnych jest jednak niezbędny do zachowania równowagi wizerunkowej całego ugrupowania $^{25}$. Powaga sprawowanego urzędu nie

23 Zob. A. Czyżyk-Cyzio, Sensacyjność dźwigniq informacji telewizyjnej, w: Media - między władzq a społeczeństwem, red. M. Szpunar, Rzeszów 2007, s. 175.

24 P. Andrzejewski, W. Kot, Medialne Public Relations, Poznań 2006, s. 31.

25 M. Jeziński, Marketing polityczny a procesy akulturacyjne. Przypadek III Rzeczpospolitej, Toruń 2004, s. 131-146. 
pozwala aktorom, w większości wypadków, na dewaluację swojej maski. Deprecjonowanie przez ośmieszanie jest zatem zabiegiem o tyle funkcjonalnym, iż skutecznie redefiniuje profil symboliczny polityka.

Kolejną funkcją rekwizytu w procesie komunikowania politycznego jest rola ikonograficzna. Warto w tym miejscu odnieść się do coraz powszechniejszej dominacji kultury obrazu. Kojarzy się ona przede wszystkim z konwencją komiksu lub właśnie z ikoną ${ }^{26}$. W ten sposób wykształca się nowa postać odbiorcy informacji - homo videns - człowiek, którego percepcja nakierowana jest na obraz wytworzony przez reklamę, czy szerzej - media. Istotą kultury wizualnej jest trend, który znakomicie wpisuje się w specyfikę funkcjonowania społeczeństw ponowoczesnych - jest to potrzeba ruchu, ciagłej zmiany, dynamicznego rozwoju sytuacji. Widownia jest grupa, której nie służy nuda - w natłoku informacji widz skupia się tylko na wybranym wycinku rzeczywistości medialnej - tej, która w sytuacji dynamicznie rozwijającej się sekwencji zdarzeń zdoła dotrzeć do niego z interesującym przekazem. Genezy tego trendu należy szukać w procesie tabloidyzacji, ale także w wieloletniej zmianie estetyki: począwszy od powstania fotografii prasowej, przez rozszerzone możliwości obrazów telewizyjnych, po barwny świat witryn internetowych ${ }^{27}$. Ta linia pokazuje, w którą stronę podążają media, za którymi powinni również zmierzać nadawcy komunikatu - jest to kierunek, w którym obrazowanie treści ma kluczowe znaczenie.

Każde spotkanie aktora z publicznością za pośrednictwem mediów ma za zadanie wywarcie przez nadawcę określonego wpływu na odbiorcę. Odbywa się to w toku procesu kompleksowego i wieloetapowego, którego pierwszą fazę stanowi ekspozycja przekazu w miejscu łatwo dostępnym dla odbiorcy, potem następuje uruchomienie uwagi i skoncentrowanie jej na komunikacie ${ }^{28}$. Polityka częstokroć wymaga zmaterializowanego zaprezentowania publiczności pewnych elementów rzeczywistości, aby przedstawić namacalny obraz podjętych decyzji. Aby widownia mogła zrozumieć aktora na scenie, niezbędny jest mu re-

26 B. Jarosz, Przestrzeń graficzna w przekazach multimedialnych dobie dominacji kultury obrazu, s. 1, www.up.krakow.pl/ktime/ref2004/jarosz.pdf [26.09.2011].

27 Ibidem, s. 2.

28 Zob. W. McGuire, Persuasion, Resistance and Attitude Change, w: Handbook of Communication, red. I. de Sola Pool, cyt. za: B. Dobek-Ostrowska, Podstawy komunikowania społecznego, Wrocław 1999. 
kwizyt, który zobrazuje podjęte działania. Wiarygodność polityka zależy również od dwóch faktów istotnych w tym punkcie rozważań. Po pierwsze, komunikat wysyłany od nadawcy do odbiorcy musi być sygnałem jasnym i niezakłóconym. Aby aktor został dobrze zrozumiany przez publiczność musi posługiwać się konkretem. Po drugie, za słowem powinien iść obraz, czyn i dowód na poparcie stawianych tez. W uzyskaniu efektu wiarygodności wspomaga aktora rekwizyt, który za pomocą mediów może zobrazować publiczności i uwiarygodnić działania podjęte na scenie politycznej. Zabiegi te - na gruncie polskim - wykorzystywane są najczęściej podczas konferencji prasowych. Rekwizyt pomaga skupić uwagę kamery czy aparatu fotograficznego i unaocznić rozważany podczas konferencji problem. Jest też wsparciem dla wystąpienia retorycznego aktora.

Ważnym i często stosowanym elementem uatrakcyjnienia wysyłanego za pośrednictwem mediów przekazu podczas tego typu spotkań jest prowokacja. Rozumiana jest ona w tym przypadku jako brutalne naruszenie obyczajów, kultury i przyzwyczajeń powszechnie przestrzeganych $^{29}$. Wprowadzony w ten sposób element sensacyjności, przekroczenia pewnych granic dobrego smaku czy odstępstwa od przyjętych za standardy reguł, ma za zadanie wzbudzić odpowiednie emocje ułatwiające dotarcie z przekazem do odbiorcy i utrwalenie go w pamięci zbiorowej publiczności. Rola owych emocji jest tu kluczowa - ekspresywne nacechowanie pewnych elementów przekazu (np. użytych rekwizytów) może mieć wpływ na ostateczny odbiór działań politycznych aktora rozumianych jako całość. Zdolność emocjonalnego oddziaływania jest z kolei tożsama z manipulowaniem publicznością, co na scenie politycznej jest umiejętnością niezwykle przydatną i pożądaną.

Konsekwentnie prezentowana przez aktora maska również wymaga zewnętrznego wsparcia i ciągłego potwierdzania swojej wiarygodności. Nie ulega wszakże wątpliwości, iż zarządzanie politycznym wizerunkiem przez aktora to jeden z głównych elementów politycznego marketingu. Coraz rzadziej stanowi on dzieło przypadku. „Zaczyna podlegać kryterium profesjonalizacji i staje się podstawowym warunkiem, który determinuje strategię wyborczą"30. Wizerunek to ,skonkretyzowany,

29 D. Jagła, Rola prowokacji w reklamie społecznej, „Zeszyty Naukowe” 2000, nr 1 , s. 83 .

${ }^{30}$ Zob. K. Giereło, Wizerunek polityka po polsku. Kampania prezydencka 2000 r., w: Kształtowanie wizerunku, red. B. Ociepka, Wrocław 2005, s. 93. 
wyrazisty i zdatny do publikacji (rozpowszechniania) obraz fizyczny człowieka z takimi dostrzegalnymi i charakterystycznymi dla niego cechami, które umożliwiają jego identyfikację"31. Jest to zatem profil jego osoby wykreowany w określonym celu i przekazywany opinii publicznej. Wizerunek, jako element zbiorowej pracy sztabu ma na celu weryfikację informacji i dostarczenie publiczności wyselekcjonowanej wiedzy za pomocą mediów. Aktorzy polityczni muszą więc zaakceptować reguły personalizacji polityki, dostosować swój wizerunek, a często i program do reguł medialnego przekazu ${ }^{32}$. Zabiegi te intensyfikują się wprawdzie w czasie kampanii wyborczych, choć główni aktorzy na politycznej scenie i ich sztaby wyposażone w specjalistyczną wiedzę, świadome są zjawiska kampanii permanentnej ${ }^{33}$.

Warto sięgnąc tutaj do psychologii, jako nauki specjalizującej się w kwestiach wywierania wpływu na ludzi, a dokładniej do jej specjalizacji skupiającej się na obszarze oddziaływania mediów. W toku komunikacji marketingowej, często wytworzony zostaje obraz danego aktora w świadomości poszczególnych członków audytorium, jak i widowni rozumianej jako całość. Perswazja w służbie budowania wizerunku ma za zadanie obdarzyć aktora cechą, którą ten w istocie nie posiada. Sens w tym, że zapotrzebowanie społeczne, na określone cechy charakteru może okazać się dla politycznego nadawcy komunikatu sprawą na tyle istotna, iż cecha ta zostaje przypisana aktorowi. Warto zadać w tym miejscu pytanie, czy w tym przypadku utożsamianie przekazów medialnych z rzeczywistością jest uzasadnione ${ }^{34}$ ?

Wykreowanie stanu rozbieżności rzeczywistości medialnej ze stanem faktycznym wydaje się jednym z głównych problemów skutecznego budowania wizerunku. Wraca tutaj temat wiarygodności jako zbieżności obrazu z prezentowaną treścią. Jeśli ten rozdźwięk jest zbyt widoczny czy też ostentacyjny - zabieg, który miał za zadanie poprawę wizerunku, może go degradować. Zjawisko to jest charakterystyczne dla prymi-

31 K. Badźmirowska-Masłowska, Wizerunek, czyli kiedy, kogo i jak można pokazywać $w$ telewizji, Warszawa 2008, s. 15.

32 Zob. A. Jaskiernia, Czynniki oddziałujace na zachowania mediów masowych w procesach wyborczych, w: Media - między władza a społeczeństwem, red. M. Szpunar, Rzeszów 2007, s. 23.

33 B. Dobek-Ostrowska, Media masowe $i$ aktorzy polityczni w świetle studiów nad komunikowaniem politycznym, Wrocław 2004, s. 244-245.

34 C. Nass, B. Reeves, Media i ludzie, Warszawa 2000, s. 95. 
tywnych kampanii, charakterystycznych dla polskiej sceny politycznej w pierwszej połowie lat 90. XX wieku. Swoistą pułapkę stanowi tu uznanie rzeczywistości medialnej za stan faktyczny. Posłużenie się perswazją następuje więc w sposób nieumiejętny - publiczność w zbyt dużym stopniu zauważa aktora, scenografię i rekwizyt, a w ograniczonym stopniu dostrzega obraz człowieka, jako niepowtarzalnej i zindywidualizowanej istoty ludzkiej. Rozdźwięk ten może dotyczyć także kwestii wykorzystania elementów teatralizacji życia politycznego. Rekwizyt nieodpowiednio dobrany do sceny czy osobowości aktora sprawia, iż obraz w masowym wyobrażeniu publiczności staje się wewnętrznie sprzeczny, a przez to, niewiarygodny ${ }^{35}$.

Bogusława Dobek-Ostrowska twierdzi, iż jednym z elementów budowania politycznego wizerunku jest proksemika, czyli nauka zajmująca się badaniem wzajemnych korelacji przestrzennych między aktorami oraz między ludźmi a otoczeniem materialnym ${ }^{36}$. Wskazuje to, iż rekwizyt jako materialny element otoczenia osoby pełniącej funkcję publiczną jest istotnym elementem $\mathrm{w}$ budowaniu obrazu polityka $\mathrm{w}$ mediach. W gruncie rzeczy celem wspomożenia kampanii wizerunkowych elementami materialnymi jest prosta zasada, by przekonać media masowe, z zasady swojej niezależne od aktorów politycznych, by chciały zamieścić te przekazy, na których zależy wytwórcom wizerunku, a unikać tych, które są dla nich szkodliwe ${ }^{37}$. Scenografia i rekwizyt w służbie politycznemu wizerunkowi mają więc za zadanie uwiarygodnić całościowy odbiór postawy danej osoby przez media masowe. Otoczenie się przedmiotami materialnymi stanowi osobliwe uzupełnienie kreowanego wizerunku; jest konsekwentnym przedłużeniem wyznaczonej strategii wizerunkowej, jednym z niewielkich trybów całej machiny medialnej, która ma za zadanie udowodnić wyborcy, iż osoba, którą publiczność obserwuje na ekranie, rzeczywiście nią jest. W tym ujęciu termin ,rekwizyt” może być utożsamiany z pojęciem „atrybutu”, który oznacza pewien element wyróżniający jednostkę spośród innych aktorów.

35 Przekonali się o tym chociażby Waldemar Pawlak w sposób nieumiejętny próbujący zniwelować poziom społecznej alienacji w odniesieniu do swojego wizerunku, czy Jacek Kuroń ,„przebrany” w postać, której publiczność uznająca rzeczywistość medialną za stan faktyczny, nie znała.

36 C. Nass, B. Reeves, op. cit., s. 245.

37 Ibidem, s. 247. 
Denis Nimmo i Roland Savage twierdzą, iż na wizerunek polityczny składają się trzy podstawowe aspekty: poznawczy, konatywny i emocjonalny ${ }^{38}$. Należy przyznać, iż rekwizyt używany często w celach perswazyjnych odnosi się do tego ostatniego elementu obrazu polityka. Przekaz silnie nacechowany emocjonalnie, wywierający na publiczności duże wrażenie, bez znaczenia czy to pozytywne, czy negatywne, bywa lepiej zapamiętywany, co rzutuje z kolei na kwestię obecności w mediach i ostatecznie - popularność wśród wyborców ${ }^{39}$.

Kolejną i ostatnią z kolei rolę rekwizytu w komunikowaniu politycznym stanowi funkcja rytualna i symboliczna. Trudna do zdefiniowania kategoria symbolu stanowi odpowiednik danego pojęcia abstrakcyjnego, który może być postrzegany zmysłowo. Ciekawie rolę symbolu w politycznym komunikowaniu przedstawiła Ewa Musiałowska twierdząc, iż „wizerunek to wyobrażenia o danych przedmiotach, które pomagają nam kategoryzować i porządkować to, z czym się stykamy [...]. W pewnym sensie kampanie PR moga pomóc w lepszym zauważeniu szczegółów, są jak aparat cyfrowy - zoomują wybrane części obrazu, poprawiają jego ostrość. Ostrość można poprawić, posługując się m.in. wyraźnymi symbolami, które mają zdolność ewokowania sensów ukrytych, bogatszych i daleko wykraczających poza proste przedstawienie" ${ }^{\text {40 }}$.

38 M. Jeziński, Marketing polityczny a procesy..., op. cit., s. 128.

39 Doskonałym przykładem uzupełniającym teoretyczną część tych rozważań jest wykorzystanie elementów ubioru jako rekwizytów uwiarygodniających wizerunek aktora na politycznej scenie. Ubiór jest częstokroć nie tylko odzwierciedleniem przynależności do klasy społecznej, grupy zawodowej, ale jego elementy są związane z określonymi typami politycznego wizerunku. Polski polityk, Poseł na Sejm RP I kadencji i przewodniczący Nowej Prawicy Janusz Korwin-Mikke uznawany jest w opracowaniach z zakresu politycznego marketingu za typ „ekscentryka”. W ślad za jego profilem psychologicznym idzie też obraz - aktor ten często wykorzystuje nietypowe części garderoby, a jego znakiem rozpoznawczym jest mucha. Chodzi tu o męski dodatek zakładany na szczególne okazje do smokingu, fraku lub garnituru. Stałe używanie tego elementu ubioru nie stanowi jeszcze dowodu na ekscentryczność jego właściciela, ale jest pewnego rodzaju odzwierciedleniem jego niekonwencjonalnych i nieszablonowych przedsięwzięć politycznych. Podobną rolę spełniała dżinsowa koszula Ministra Pracy i Polityki Społecznej w latach 1989-1990 i 1992-1993 Jacka Kuronia, który unikając eleganckich garniturów, charakterystycznych dla najwyższych urzędników państwowych, starał się zbliżyć do najuboższych mieszkańców Polski, w których interesie działał.

40 Zob. E. Musiałowska, Budowanie wizerunku poprzez wykorzystanie symbolu, w: B. Ociepka (red.), op. cit., s. 55. 
Stąd wykorzystywanie zabiegów o charakterze symbolicznym było $\mathrm{i}$ jest stosowane w marketingu politycznym na dużą skalę. Symbol od zawsze stanowił źródło informacji, która jest kwintesencją procesu komunikowania, także tego politycznego ${ }^{41}$. Dziś symbol w świetle teorii produktu politycznego, jako towaru czy usługi na tradycyjnie rozumianym rynku konsumpcyjnym, ma bardzo duże znaczenie, gdyż często stanowi o wartości tego produktu. „Komunikat taki, poprzez działanie poza obszarem języka, dociera do milionów ludzi, a im częściej emitowany, tym większa jego moc i bardziej zapada w pamięć odbiorcy"42. Symbol posiada także tę właściwość, iż może odwoływać się do wielu sfer jednocześnie i odnosić do wielu pól semantycznych, stając się przez to atrakcyjnym dla szerokiej publiczności korzystającej z mediów masowych. „Poszerzając zakres skojarzeniowy danego pojęcia, polityk [...] odwołuje się do bardzo szerokiego pola podzielanych przez wyborców wartości i tym samym stara się czynić swoją wypowiedź atrakcyjną dla jak najszerszej publiczności" ${ }^{43}$. Szerokie pole interpretacyjne w odniesieniu do symbolu pomaga $\mathrm{w}$ manipulowaniu wrażeniami publiczności: świadomie wysyłane sygnały umożliwiają wywołanie w odbiorcy przeświadczenia, iż sam doszedł do oczywistych wniosków. W przypadku znaku symbolicznego, czyli symbolu, zarówno materialna forma znaku, jak i jego związek z odniesieniem są całkowicie umowne, konwencjonalne. Znak jest rozpoznawalny tylko na tyle, o ile postrzegająca go jednostka zna ten związek lub się go domyśla ${ }^{44}$. Podobnie jak w przypadku wspomnianej wcześniej ironii, zmniejsza to dystans między nadawcą a odbiorcą komunikatu.

Zgoła inną rolę pełnią natomiast symbole głęboko zakorzenione w świadomości zbiorowej dużych społeczności, w sposób jednoznaczny konotowane $\mathrm{z}$ określonymi materialnymi przedmiotami o charakterze symbolicznym. Stanowią one wyróżnik, który integruje symbolikę danego przekazu z ogólnym wyobrażeniem społeczeństwa na temat aktora indywidualnego czy zbiorowego. Za przykład mogą posłużyć tutaj cho-

41 T. Brzeziński, B. Michalak, Kolor i symbol jako wizualne środki emocjonalnego oddziatywania $w$ polityce, w: Marketing polityczny $w$ poszukiwaniu strategii wyborczego sukcesu, red. M. Jeziński, Toruń 2005, s. 168.

42 Ibidem, s. 170.

43 Cyt. za: M. Jeziński, Marketing polityczny a procesy..., op. cit., s. 93

44 M. Mrozowski, Media masowe. Władza, rozrywka i biznes, Warszawa 2001, s. 276 . 
ciażby ruchy socjaldemokratyczne czy socjalistyczne, których rekwizyty wykorzystują kolor czerwony, jako stosunkowo czytelny sygnał dla publiczności o lewicowych poglądach politycznych ${ }^{45}$. Stąd, podczas wszelkiego rodzaju wydarzeń na politycznej scenie, obecność czerwonych sztandarów i wszelkiego rodzaju innych symbolicznych atrybutów wyróżniających aktora indywidualnego czy zbiorowego jako związanego z lewicową myślą polityczną. Analogicznie można odnieść tę prawidłowość do niemal każdych środowisk politycznych, jak chociażby do ruchów narodowych i nacjonalistycznych (symbole narodowe, barwy narodowe czy zakorzenione czytelne symbole narodowej martyrologii) czy ekologicznych (wykorzystanie w symbolice i użytych rekwizytach koloru zielonego oraz odwołanie się do motywów industrialnych).

Funkcja symboliczna rekwizytu na politycznej scenie to przede wszystkim pozycjonowanie danego aktora czy środowiska politycznego i przypisanie ich do określonego nurtu. Mimo stosunkowo dużej płynności wyborców na polskiej scenie politycznej, identyfikacja z określonymi ruchami jest wciąż istotnym czynnikiem w procesie podejmowania decyzji wyborczej. Umieszczając tę prawidłowość w ramach egzemplifikacji można stwierdzić, iż aby zorientowany lewicowo wyborca zagłosował na lewicową partię, musi być przekonywany o jej lewicowości. W dobie zatarcia polaryzacji na osi prawica-lewica zabiegi tego typu wydają się być w dwójnasób istotne. Stąd też częste odwoływanie się do symbolicznej funkcji rekwizytów wykorzystywanych podczas wystapień publicznych - zidentyfikowanie swojego ,ja” poprzez aranżacje otoczenia skutkuje wysłaniem przez media konkretnego sygnału do potencjalnego elektoratu.

Symbole pełniące jednocześnie funkcje rekwizytów są bardzo często wykorzystywane w realiach życia politycznego. Aktorzy chcąc wizualnie umiejscowić swoją osobę w danym środowisku umieszczają w swoim otoczeniu przedmioty-znaki mające ich scharakteryzować i pozycjonować w oczach widowni obserwującej scenę poprzez masowe media. W związku z tym, aktorzy polityczni chętnie występują na tle symboli narodowych czy odwołujących się do konkretnej formacji światopoglądowej. Widoczny element symboliczny wykorzystywany jest np. w postaci znaczków przypinanych do elementów garderoby - marynarki lub płaszcza. Zabieg ten jest o tyle skuteczny, iż narzędzia, którymi

45 M. Jeziński, Marketing polityczny a procesy..., op. cit., s. 94. 
posługują się media wizualne i audiowizualne skupiają swoje obiektywy przede wszystkim na osobie kandydata. Symbol znajdujący się w niedużej odległości czy wręcz na samym kandydacie ma więc dużą szansę zaistnieć $\mathrm{w}$ relacjach prasowych $\mathrm{z}$ politycznej sceny ${ }^{46}$.

$\mathrm{W}$ polskich warunkach społeczno-politycznych nieco inne, acz doniosłe znaczenie mają symbole rytualne i sakralne. W szczególności istotne są tu te związane $\mathrm{z}$ wiarą katolicką, którą według badań CBOS z 2009 roku deklaruje 94,7\% Polaków ${ }^{47}$. Jak zauważa Paul Ricoeur, symbole wykorzystywane politycznie sprowadzają się do trzech wymiarów: onejrycznego, poetyckiego i kosmicznego. Ten ostatni odnosi się przede wszystkim do kwestii sakralnych. Tutaj także zauważalne jest silne nacechowanie emocjonalne związane $\mathrm{z}$ wartościami moralnymi i religijnością ${ }^{48}$. Odsetek Polaków deklarujących się jako wyznawcy religii katolickiej na poziomie niemal $95 \%$ to większa liczba - w przeliczeniu na jednostki - niż ilość osób uprawnionych do głosowania, dlatego nietrudno dojść do wniosku, iż tak olbrzymia publiczność stanowi dla aktora wielomilionowy potencjalny elektorat. Podkreślenie religijnej identyfikacji $\mathrm{w}$ postaci zmaterializowanych symboli sakralnych jest więc kolejną funkcją przedmiotu, który ma za pośrednictwem mediów masowych zmniejszyć dystans między aktorem a obserwującą go na co dzień widownią. Atrybuty takie jak krzyże, medaliki, obrazy bóstw i świętych oraz wszelkie inne przedmioty spełniające funkcje sakralne są więc często wykorzystywane podczas wydarzeń na politycznej scenie lub stosowane jako stały element politycznego wizerunku.

46 Jako przykład mogą tu posłużyć rekwizyty zawierające elementy symboliki narodowej, chętnie wykorzystywane podczas zawodów sportowych, w szczególności w czasie spotkań drużyn narodowych. Jako że wydarzenia tego typu cieszą się bardzo dużą oglądalnością, a sport jako pewnego rodzaju szlachetna idea rywalizacji budzi pozytywne skojarzenia, aktorzy polityczni chętnie korzystają z możliwości pojawienia się na stadionach i innych obiektach sportowych. Typowym rekwizytem wykorzystywanym podczas zawodów piłkarskich jest szalik w barwach państwowych, wykorzystujących symbolikę narodową. Nie tylko przedmiot taki solidaryzuje aktora z kibicami sportowymi, często noszącymi na szyi tę charakterystyczną część garderoby, ale także wysyła poprzez media wyraźny sygnał solidarności polityka z narodem i utożsamiania się z jego wartościami.

47 Wiara i religijność Polaków dwadzieścia lat po rozpoczęciu przemian ustrojowych, Warszawa 2009, www.cbos.pl/SPISKOM.POL/2009/K_034_09.pdf [3.03.2010].

48 M. Jeziński, Marketing polityczny a procesy..., op. cit., s. 94. 


\section{Zakończenie}

Codzienne odgrywanie ról jest stałym elementem sceny, także tej politycznej. Aktor jednocześnie może korzystać z maski parlamentarzysty, politycznego mentora, przykładnego katolika, partyjnego błazna, oponenta w debacie. Każda z masek wymaga odpowiedniej oprawy scenicznej: scenografii, rekwizytu, partnerów na scenie w kreacjach pierwszoplanowych, jak i statystów. Można z dużym prawdopodobieństwem założyć, iż gra aktorów sceny politycznej - także tej polskiej - jest coraz bardziej świadoma i zaplanowana. Podczas gdy w wyborach z 1990 r. pewna nieznajomość mechanizmów rządzących marketingiem politycznym oraz spora doza niedoświadczenia sprawiły, iż komitety działały w sposób chaotyczny, tak w ostatnich kilku latach rozwój badań i świadomości bycia pod obserwacją sprawiły, iż dobór scenografii i rekwizytów jest dobrze zaplanowanym zabiegiem z zakresu politycznego $P R$. Jeśli nie zajmują się tą kwestią specjaliści, to sam aktor posiada zmysł wyboru odpowiednich środków do spopularyzowania swojej osoby, przy jednoczesnym zachowaniu pozorów naturalności, szczerości i wiarygodności swoich działań.

Stąd coraz większy poziom profesjonalizmu w odniesieniu do drugiej podjętej kwestii - wykorzystania odpowiednich środków na drodze do osiagnnięcia celu. Aby wiarygodnie zaprezentować się przed publicznością, aktor musi dobrać narzędzia w sposób niekolidujący z jego wizerunkiem; nadać komunikat wizualny za pomocą odpowiednich środków przekazu, skierować informację do odpowiednich segmentów potencjalnych wyborców zasiadających na widowni. Wraz ze wzrostem profesjonalizacji w tym zakresie, wzrost powinna osiagnąć także skuteczność. Odpowiedź na pytanie o cel tych zabiegów, wydaje się być niejednoznaczna. Istotnie, największe znaczenie wydają się mieć: popularyzacja własnego ,ja” scenicznego, zdobycie sympatii czy poklasku wśród zwolenników, przekonywanie do swojej osoby niezdecydowanego elektoratu. Szerzej - nadrzędnym celem wydaje się być pozostanie na scenie oraz brak zgody na zagłuszanie własnych komunikatów w szumie analizowanych przez widownię danych. Wydaje się jednak, że znaczenie ma także - a może przede wszystkim - uzyskanie pewnego rodzaju ,przewagi" i umiejscowienie swojej kreacji aktorskiej wyżej, niż założona kwestia. Owa przewaga może dotyczyć konkretnego drugiego ,ja” scenicznego, informacji wyżej pozycjonowanej w mediach itp. Jednym z narzędzi polityki uzyskiwania przewagi nad konkurentem jest marke- 
tingowo zagospodarowany rekwizyt stanowiący postmodernistyczne narzędzie komunikacji politycznej aktora $\mathrm{z}$ widownią, z uwzględnieniem szczególnej roli mediów jako pośrednika w tym procesie.

\section{Props as a tool of political communication}

\section{Summary}

A product that needs to be promoted and sold and the information published in the media alike undergo a process of 'merchandization'. Therefore a given message has to be included in the mainstream media content observing the principle of maximized profit, or, in this case, reaching a mass audience. This generates the realm of specialized competition to win an individual's interest, named 'attention economics' by Georg Franck. In order to get the message across to concrete recipients, broadcasters have to take appropriate steps to prevent their information from being rejected. For this purpose the actors on the political stage apply modern communication tools to (directly) attract the attention of the (indirectly) mass media audience. One such tool is a prop that can be used as a means to deprecate an opponent, an element of a political image, a source of symbolism, or an iconographic form used to present the issue in question. Trying to attract the attention of mediators in the communication process is a strategy to win popularity, which is in turn supposed to increase the probability of success during the elections, which increasingly more often are becoming a pure popularity poll. 